\title{
Delamaran trilobites from the La Laja Formation, San Juan, Argentina
}

\author{
Rodolfo D. FOGLIA ${ }^{1}$ and N. Emilio VACCARI ${ }^{1}$
}

\begin{abstract}
The La Laja Formation lies exposed almost continuously along the western margin of two hill ranges, i.e., the Sierra Chica de Zonda and Sierra de Villicum. This limestone unit bears a remarkable fauna of Cambrian trilobites. In this work we analyse the Delamaran trilobite fauna from the upper part of the El Estero Member and the lower third of the Soldano Member of the La Laja Formation. Taxa described are Glossopleura walcotti Poulsen, Glossopleura lodensis (Clark), Fieldaspis sp., and Prozacanthoides zondaensis n. sp. The Poliella denticulata, Mexicella mexicana?, and Glossopleura walcotti Zones are documented; these had been previously included in a hiatus. Trilobites-based correlations are established between the La Laja Formation and olistoliths of the Western Precordillera. Additional correlations are also suggested between the Precordillera and different localities in Laurentia. Finally, we discuss the biogeographic implications of the described material. Delamaran taxa reported from the La Laja Formation are characteristic and so far restricted to Laurentia. Analysis of the trilobite fauna from this unit supports the allochtonous origin of the Precordillera.

Resumen. Trilobites delamarianos de la Formación la laja, SAn JuAN, Argentina. La Formación La Laja aflora de forma prácticamente ininterrumpida a lo largo del margen occidental de las sierras Chica de Zonda y Villicum, San Juan, Argentina. Sus calizas son portadoras de una importante fauna de trilobites cámbricos. En este trabajo se describe y analiza la trilobitofauna del Delamariano de la Formación La Laja, ubicada entre los últimos metros del Miembro El Estero y el tercio inferior del Miembro Soldano. Se determinaron las biozonas de Poliella denticulata, Mexicella mexicana? y Glossopleura walcotti, las que en trabajos recientes han sido incluidas en un hiato faunístico. Los taxones determinados en este trabajo son: Glossopleura walcotti Poulsen, Glossopleura lodensis (Clark), Fieldaspis sp. y Prozacanthoides zondaensis n. sp. Se realizaron correlaciones entre los niveles de la Formación La Laja y olistolitos de Precordillera Occidental. También se correlacionaron los niveles de Precordillera con otros en diferentes localidades de Laurentia. Los géneros documentados en este trabajo para el Delamariano de la Formación La Laja son característicos y restringidos a Laurentia. El análisis de toda la fauna de la Formacion La Laja, apoya el modelo alóctono para el origen de Precordillera.
\end{abstract}

Key words. Cambrian. Delamaran. Trilobites. Argentina. Precordillera.

Palabras clave. Cámbrico. Delamariano. Trilobites. Argentina. Precordillera.

\section{Introduction}

Trilobites from the La Laja Formation are fundamental for understanding the early history of the Precordillera terrane. Different authors have studied the faunas contained in this unit, dealing mainly with its biostratigraphic aspects. However, systematic studies of the trilobites are scarce and this study on the Delamaran trilobites from the La Laja Formation is a contribution towards broadening knowledge on this important group of fossils.

Kayser (1876) and Stelzner (1923-1924) described the first Cambrian trilobites from the Argentine

1CONICET. CICTERRA-CIPAL. Centro de Investigaciones Paleobiológicas, Facultad de Ciencias Exactas, Físicas y Naturales, Universidad Nacional de Córdoba. Av. Vélez Sarsfield 299, 5000 Córdoba, Argentina.rfoglia@efn.uncor.edu; evaccari@efn.uncor.edu

CA Asociación Paleontológica Argentina
Precordillera (San Juan Province). These trilobites were later revised by Harrington and Leanza (1943), who identified the existence of the Middle Cambrian in the Precordillera. Poulsen (1958) acknowledged the presence of the Glossopleura Zone in the Cambrian of Argentina based on specimens of Glossopleura Poulsen, 1927, from San Isidro (Mendoza Province). This established the first zonation for intercontinental correlation of the Cambrian in the Precordillera. In addition, Poulsen (1958) inferred the Glossopleura Zone in the La Laja Formation (Quebrada La Laja and Quebrada Juan Pobre in Sierra Chica de Zonda), based on species it has in common with the same Zone in exposures at San Isidro, such as Mendospidella digesta (Leanza, 1947) and Kistocare mendozanum (Rusconi, 1945).

Bordonaro (1986) recognized the Bonnia-Olenellus Zone in the El Estero Member of the La Laja Formation based on the occurrence of Olenellus zondaen-

AMGHB2-0002-7014/10\$00.00+.50 
sis Bordonaro, 1986, Bonnia villicumica Bordonaro, 1986, Antagmus argentinus Bordonaro, 1986, and Bristolia sp. This fossil assemblage was recently revised by Foglia and Vaccari (2006a) and referred to the uppermost part of the upper Bonnia-Olenellus Zone. The Bonnia-Olenellus Zone was also documented within the Cerro Totora Formation at Quebrada La Angostura (La Rioja Province), based on the presence of Arcuolenellus megafrontalis (Vaccari) (see Vaccari, 1988; Astini and Vaccari, 1996). Vaccari and Bordonaro (1993) recognized the Bonnia-Olenellus Zone in olistolith C1 at Los Túneles, on the basis of the record of Olenellus? sp., Prozacanthoides sp. (see discussion of the genus below), and Sombrerella argentina Vaccari and Bordonaro, 1993.

Bordonaro (2003a, 2003b) mentioned a hiatus spanning the Plagiura-Poliella and Albertella zones and also possibly the Glossopleura Zone in the Eastern Precordillera. However, Foglia and Vaccari (2006b) recognized the presence of the Glossopleura Zone and also possibly the Albertella Zone in the Soldano Member of the La Laja Formation. Records of the Glossopleura Zone in the Western Precordillera are limited to reports of its occurrence in the olistoliths of Ojos de Agua and Los Ratones (Bordonaro and Banchig $(1990,1995,1996)$. Poorly preserved material at these localities was identified as Glossopleura aff. leona Lochman and Glossopleura sp. More recently, Bordonaro et al. (2008) published a biostratigraphic model for the early Marjumian in the Precordillera and correlated different sections in the Eastern and Western Precordillera. Finally, Bordonaro and Pratt (2008a, 2008b) recognized the Eokochaspis nodosa Zone in the lowermost part of the Soldano Member, and the Glossopleura and Ehmaniella zones in the middle and upper parts of this unit. It is important to point out that none of these contributions illustrated specimens of these taxa from the La Laja Formation and references are restricted to the text only.

In this work, two species of Glossopleura are described and illustrated, documenting precisely for the first time the stratigraphic range of the Glossopleura walcotti Zone in Eastern Precordillera. Material collected from beds immediately below the base of the Glossopleura walcotti Zone is also illustrated and discussed from a biostratigraphic point of view. This material comes from the Poliella denticulata Zone at the Cerro Molles section and possibly from the Mexicella mexicana Zone at the Quebrada La Laja section. Localities mentioned in the text are shown in figure 1.

Cambrian trilobites from the Precordillera in general (e.g., Poulsen, 1958; Borrello, 1963; Vaccari, 1994) and those from the La Laja Formation in particular, show close affinities with Laurentian faunas. In this sense, data drawn from the material described herein may help resolving the recent controversy on the

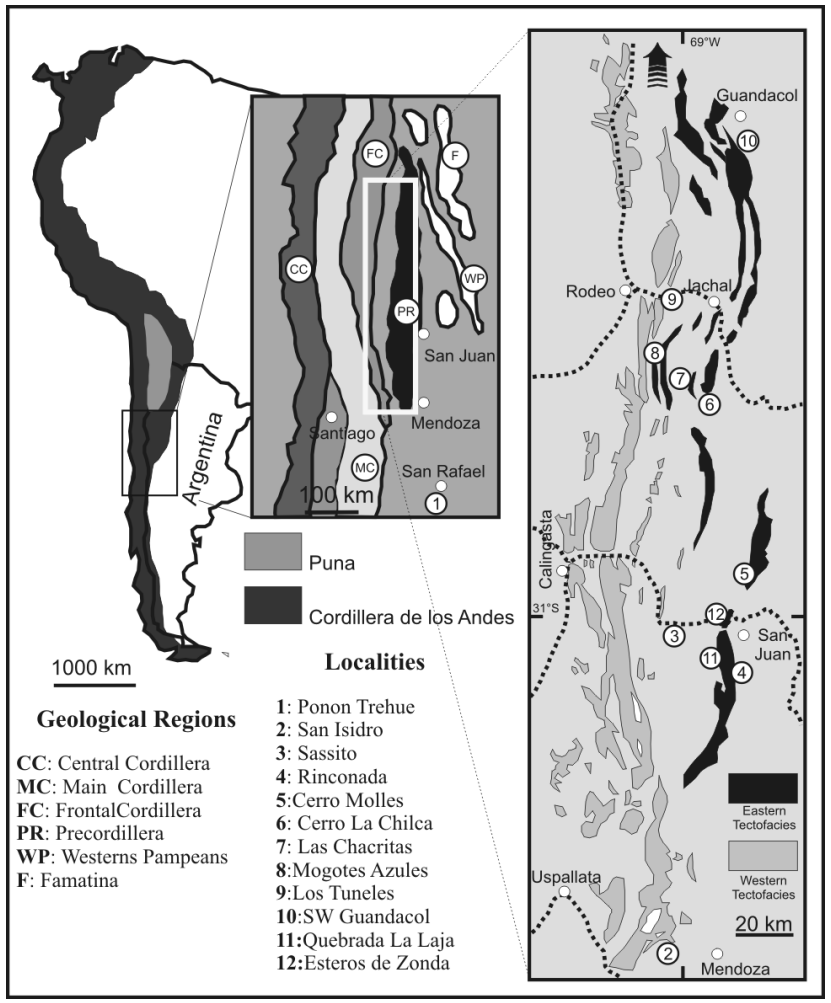

Figure 1. Location map showing the cities and localities cited in the text (modified from Astini, 1998) / mapa de ubicación, en el que se observan las ciudades y localidades citadas en el texto (modificado de Astini, 1998).

Gondwanan (e.g., Finney et al., 2003, 2005; Finney, 2007; Aceñolaza and Toselli, 2007) or Laurentian (e.g., Vaccari, 1994; Astini et al., 1995, 1996; Thomas and Astini, 1999; Benedetto, 2004) origin of the Precordillera.

\section{Localities and stratigraphy}

The La Laja Formation is exposed with significant lateral continuity along the western slope of the Sierra de Villicum and the Sierra Chica de Zonda. Originally described by Borrello (1962), the unit is mainly composed of carbonate deposits with mixed carbonate-siliciclastic intervals, especially in the lower part of the unit (e.g., Bordonaro, 1980; Keller, 1999; Gómez and Astini, 2006). Baldis and Bordonaro (1981) defined four members in the La Laja Formation, namely from bottom to top El Estero, Soldano, Rivadavia, and Juan Pobre members. Based on sedimentologic and stratigraphic differences, Gómez and Astini (2006) added the Las Torres Member between the Juan Pobre Member and the overlying Zonda Formation. According to Gómez and Astini (2006), the facies associations of the La Laja Formation are interpreted as representing shallow marine environments, ranging from relatively 


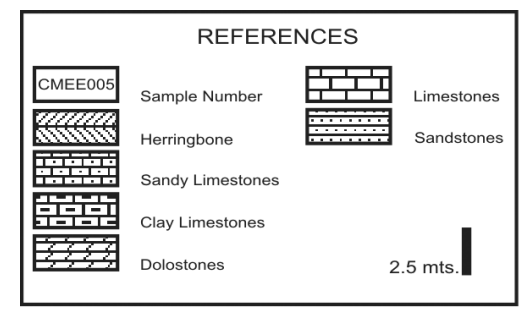

La Laja Section

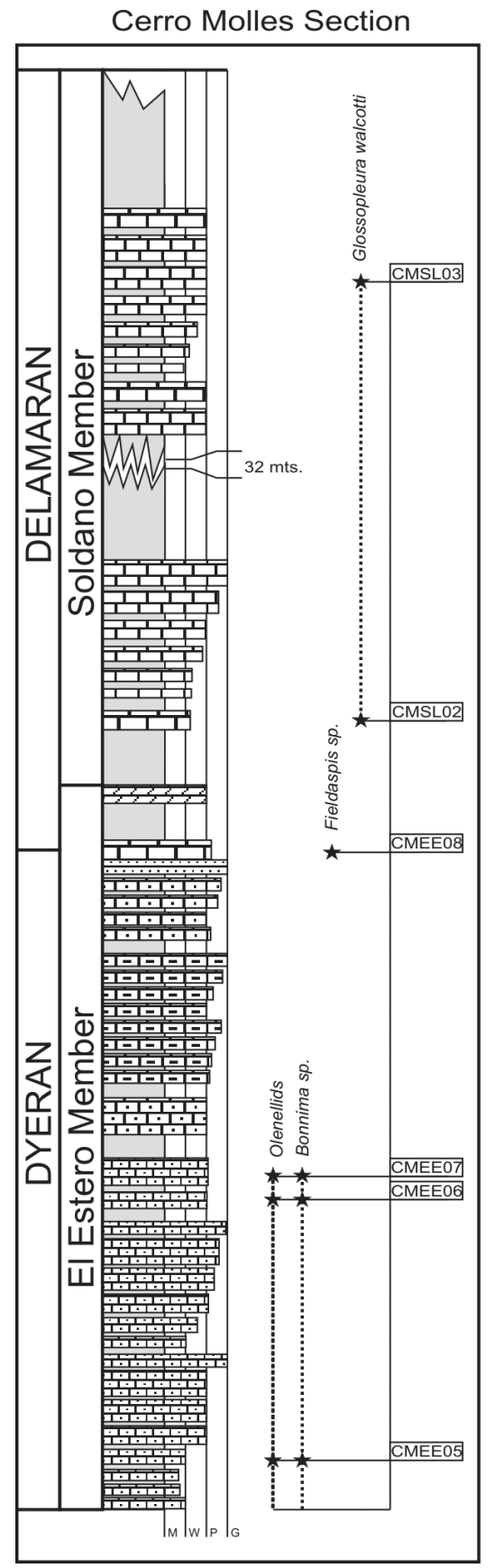

Esteros de Zonda Section

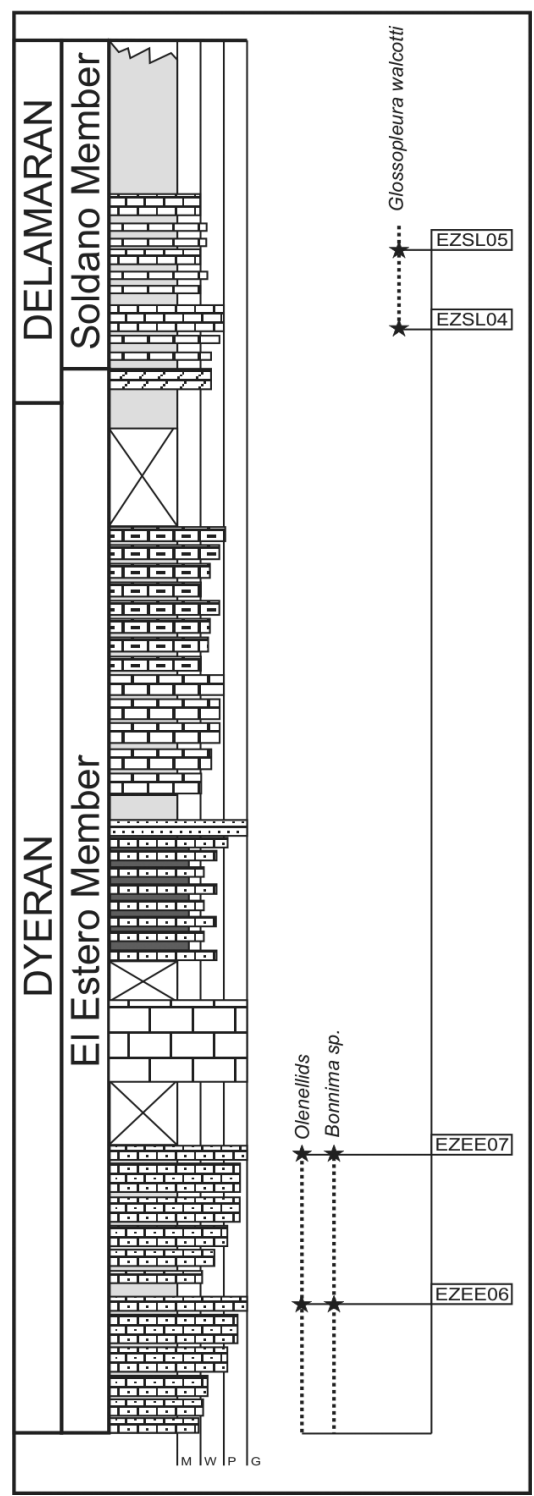

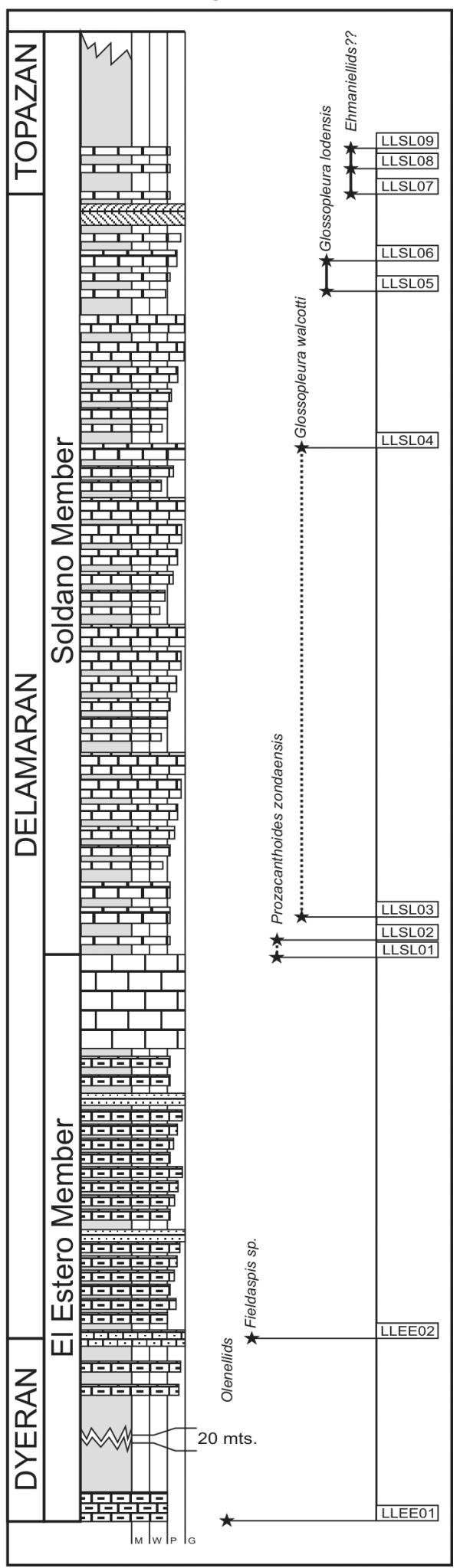

Figure 2. Stratigraphic log of the La Laja Formation exposed at Quebrada La Laja, Esteros de Zonda and Cerro Molles sections, and vertical distribution of trilobites / columna estratigráfica de la Formacion La Laja expuesta en las secciones de Quebrada La Laja, Esteros de Zonda y Cerro Molles, y distribucion vertical de trilobites.

deep subtidal to very shallow subtidal-intertidal settings. The material illustrated herein comes from the lower third of the Soldano Member and the upper part of the El Estero Member (see figure 2). 
All material is housed in the Centro de Investigaciones Paleobiológicas (CIPAL), Universidad Nacional de Córdoba, Córdoba, Argentina (prefixed CEGH-UNC).

\section{Systematic paleontology}

Order CORYNEXOCHIDA Kobayashi, 1935

Family DOLICHOMETOPIDAE Walcott, 1916

Genus Glossopleura Poulsen, 1927

Type Species. Dolichometopus boccar Walcott, 1916.

Remarks. Sundberg (2005) recently revised the type species G. boccar (Walcott) based on numerous collections; he highlighted its intraspecific variability and synonymized at least six species defined after introduction of G. boccar. Some of the characters mentioned by Sundberg as variable are pygidium convexity, degree of expansion of the frontal lobe, development of cranidial furrows, and depth of pleural furrows of the pygidium. The author suggested that some variable features such as the presence of a prominent S1 in the specimens preserved in shales are preservational differences and do not represent diagnostic specific characters. Glossopleura species are in need of revision, as many of them were based on single specimens and their variability ranges remain unknown. Such a study lies beyond the scope of the present contribution.

\section{Glossopleura walcotti Poulsen, 1927} Figure 4.10-23

1927. Glossopleura walcotti Poulsen; Poulsen, p. 268, pl. 16, figs. 20 30.

1964. Glossopleura walcotti Poulsen; Poulsen, p. 25, pl. 1, figs. 2-4. 1979. Glossopleura walcotti Poulsen; Palmer in Palmer and Halley (part), p. 79, figs. 6-8, 11-13, 16-19, non figs. 14-15.

1995. Glossopleura aff. leona Lochman; Bordonaro and Banchig, pl. 2, figs. 13-14.

2009. Glossopleura walcotti Poulsen; Benedetto et al., fig. $2 \mathrm{~g}$.

Material examined. One articulated specimen, 44 cranidia, 12 librigenae and 30 pygidia; CEGH-UNC 23686/CEGH-UNC 23778.

Occurrence. Beds LLSL01, LLSL02, and LLSL03, Soldano Member, La Laja Formation, La Laja section; beds CMSL02 and CMSL03, Soldano Member, La Laja Formation, Cerro Molles section; beds EZSL04 and EZSL05, Soldano Member, La Laja Formation, Esteros de Zonda section.

Description. Cranidium outline trapezoidal, width/ length ratio varying between 1.05 and 1.20. Glabella clearly defined by abaxially concave axial furrows; furrows usually ending in very distinct pit located in

AMEGHINIANA 47 (4), 2010 front of anterior end of palpebral lobe. Glabella transversally and longitudinally convex; frontal lobe clearly expanded laterally. Ratio between maximum and minimum width of glabella ranging between 1.5 and 1.7. Glabella with four pairs of very shallow and poorly defined glabellar furrows. Pair S1 strongly sloping inwards and backward, describing an angle varying between $45^{\circ}$ and $60^{\circ}$ respect of sagittal line. Pair S2 oriented almost transversally; S3 and S4 clearly oriented anteriorly. Palpebral lobes well defined by abaxially convex furrows; intraocular areas convex, width (trans.) about $0.30-0.35$ of cranidium maximum width. Occipital furrow well defined, relatively wide. Occipital ring conspicuous, uniformly wide transversally. Occipital ring showing slight posterior node in some specimens. Anterior branch of facial suture starting at anterior end of palpebral lobe and then running outwards and anteriorly; posterior branch developing from posterior end of palpebral lobe and running outwards and slightly backwards to meet posterior furrow of cranidium, then turning rearwards and slightly outwards. Cranidium ornamented with fine lines in sinuous terraces on anterior part of frontal lobe of glabella. Weak ornamentation resembling fingerprints around occipital node.

Librigena with convex circumocular suture; posterior furrow well defined and with clear margin. Margin is flat and widening posteriorly. Librigena ornamented with lines in sinuous terraces, beginning perpendicular to lateral edge, then sloping posteriorly and becoming almost parallel to outline. These lines continue onto the genal spine and perpendicular to it.

Seven thoracic segments; pleurae ending in dorsally flattened spines; spines slightly backwards. Thoracic segments with middle node in axial ring. Although not all pleurae are the same size, a macropleura was not observed. Ornamentation of thorax characterized by fine impressions similar to fingerprints covering axial nodes, and by fine sinuous lines in terraces located at ends of pleurae.

Pygidium semicircular, sometimes elliptical in larger specimens; width/length ratio in the latter varying between 1.6 and 1.7. Axis prominent and strongly convex, relatively short, cylindrical or slightly conical; five axial rings and a terminal piece; inter-ring furrows moderately marked. Pleural furrows narrow and well-marked, continuing along pleural field to join border furrow. Border concave and well defined by border furrow. Pygidium ornamented with nodes on the axis, around which develops a pattern similar to the one described for pleural segments. Lines in sinuous terraces beginning perpendicular to edge of furrow, then turning anteriorly and runnning parallel to outline of pygidium.

Discussion. The specimens from the Precordillera 
are indistinguishable in their cephalic and pygidial characters from the type material of Glosssopleura walcotti Poulsen from the Cape Wood Formation in northwestern Greenland (Poulsen, 1927, p. 268, pl. 16, figs. 20-30). They are also identical to part of the material referred to this species in the Carrara Formation of the Great Basin (Palmer in Palmer and Halley, 1979, pl. 16, figs. 6-8, 11-13, 16-19). However, two pygidia referred to G. walcotti by Palmer (Palmer and Halley, 1979, pl. 16, figs. 14-15) show granules on the pleural ribs of the pygidium. This feature is not present in the type material from Greenland or in any of the specimens from the Precordillera, suggesting that the material from the Carrara Formation may probably belong to a different species.

\section{Glossopleura lodensis (Clark, 1921)}

Figure 4.1-9

1921. Bathyuriscus howelli lodensis Clark.

1928. Dolichmetopus? lodensis (Clark); Resser, p. 10, pl. 3, fig. 9.

1935. Glossopleura lodensis (Clark); Resser, p. 34.

1979. ? Glossopleura lodensis (Clark); Palmer in Palmer and Halley

(part), p. 78, pl. 16, figs. 1-3, 10 non figs. 4-5, 9

Material examined. Twelve cranidia, four librigenae and 17 pygidia; CEGH-UNC 23779/CEGH-UNC 23810.

Occurrence. Beds LLSL04, LLSL05, Soldano Member, La Laja Formation, La Laja section.

Description. Cranidium nearly trapezoidal; width/ length ratio varying between 0.95 and 1.10. Glabella clearly defined by axial furrows, straight and slightly curved outwards at anterior end. Glabella transversally and longitudinally convex; frontal lobe expanded anteriorly and slightly laterally. Maximum/minimum ratio of glabella width 1.1-1.3. Four pairs of superficial and indistinct glabellar furrows. Pair S1 (only observed in some specimens) sloping inwards and backwards, meeting sagittal line at an angle of $40^{\circ}-50^{\circ}$. Pair S2 oriented almost horizontally; pairs S3 and S4 clearly oriented inwards and forwards. Palpebral lobes well defined by abaxially convex furrows. Intraocular areas convex and reaching $0.25-0.30$ of cranidium maximum width. Occipital furrow clearly defining constantly wide (transversally) occipital ring. Posterior branch of facial suture starting strongly divergent outwards and slightly backwards respect of posterior furrow of cranidium, then turning backwards to meet posterior border of cranidium. Anterior part of frontal lobe of glabella ornamented with fine sinuous terraced lines.

Librigena with convex and relatively narrow genal field and very well defined posterior and border furrows. Border flat, its width increasing towards posterior region. Genal spine beginning at genal angle and running posterirorly and outwardly.
Ornamentation of librigena consisting of lines in sinuous terraces, beginning perpedicular to middle sector of border furrow, then becoming parallel to outline; lines continuing into genal spine, almost perpendicular to axis of spine.

Pygidium outline semicircular; width/length ratio 1.7-1.9. Pygaxis prominent, strongly convex, cylindrical, including five to six axial rings and ending in a terminal piece. Pleural furrows very distinct and strongly marked right down to edge of pygidium. Lateral and posterior borders concave, only defined by change in slope. Pygidium ornamented with discrete lines in sinuous terraces near border, less noticeable than in other species of the genus.

Discussion. Glossopleura lodensis (Clark) was defined on the basis of an articulated specimen from the Mohave Desert and was later illustrated again by Resser (1928, pl. 3, fig. 9). The most distinctive character of this species is a long glabella, with relatively short palpebral lobes, a long spine in the fifth thoracic segment, and a pygidium with pleural furrows that cross the border. Although articulated specimens are not available in our collection, cranidia and pygidia with the same characteristics as the holotype of $G$. lodensis occur in the same levels.

Palmer referred some specimens from the Carrara Formation to this species (Palmer and Halley, 1979, pl. 16, figs. 1-5, 9-10). These specimens show a great variability, and probably more than a single species is represented. Only the specimen depictd by Palmer (1979, pl. 16 fig. 10) exhibits pleural furrows that cross the wide border and thus could be tentatively assigned to $G$. lodensis.

G. lodensis as revised here differs from G. walcotti by the shorter palpebral lobes, the longer glabella, and by the pleural furrows that distinctly cross the wide border of the pygidium.

\section{Family ZANANTHOIDIDAE Swinnerton, 1915}

\section{Genus Prozacanthoides Resser, 1937}

Type species. Olenoides stissingensis Dwight, 1889, p. 147, pl. 6, figs. 9-5.

Comments. Palmer (in Palmer and Halley, 1979, p. 97) indicated that the diagnosis of Prozacanthoides given by Resser (1937) was not based on the features of the type species, i.e., Olenoides stissingensis Dwight, 1889. Likewise, based on a revision of the type material, Palmer pointed out the characters that differentiate Prozacanthoides from the rest of the genera included in the family, such as the relatively short palpebral lobes, the subparallel anterior branch of the facial suture, the subtriangular posterolateral projection, and the three strong pairs of spines on the 
lateral margins of the pygidium, of which the posterior pair is the longest and most separate (Palmer and Halley, 1979, p. 97). Considering these characters, Palmer restricted the genus Prozacanthoides to the type species. We fully concur with this author and following his concept we define here a new species from the section at Quebrada La Laja.

\section{Prozacanthoides zondaensis n. $\mathrm{sp}$. Figure 5.1-17, 22-26}

Material examined. Seventeen cranidia, one librigena, four hypostomes and twenty seven pygidia; CEGH-UNC 23637/CEGHUNC 23685.

Occurrence. Bed LLEE04. El Estero Member, La Laja Formation, La Laja section.

Etymology. After Sierra Chica de Zonda.

Holotype. CEGH-UNC 23640. Pygidium.

Diagnosis. Prozacanthoides with three pairs of tubular marginal spines; posterior pair very long and stout.

Description. Cranidium trapezoidal; glabella elongate, rectangular, clearly convex transversally, defined by parallel or slightly inwardly divergent axial furrows. Four pairs of glabellar furrows; pair S1 deepest of the four and oriented backwards; pair S2 almost transversal to axis of glabella; S3 and S4 (when observable) distinctly oriented anteriorly. Some specimens showing well-defined pit at intersection of S4 and axial furrow. Anterior border of cranidium well defined, concave, external curvature radius always larger than curvature radius of glabella frontal lobe. Preglabellar furrow always conspicuous, its width increasing abaxially. Intraocular areas convex, always lower than glabella. Palpebral lobe long, convex, and clearly defined by furrow. Anterior branch of suture beginning at anterior end of palpebral lobe, then running outwards and anteriorly, obliquely crossing pre-glabellar furrow. Posterior branch of suture beginning at posterior end of palpebral lobe, then running clearly outwards and slightly backwards to contact posterior furrow of cranidium. Occipital furrow always very well defined, although narrow and shallow. Occipital ring triangular and transversally convex. No specimens with nodules or spines in occipital ring. Ornamentation of cranidium consisting of only fine terraced lines on anterior margin, running almost parallel to head outline.

Librigena convex, triangular, with well defined albeit narrow and shallow marginal furrow. Margin convex, its width increasing backwards to gradually form genal spine. Librigena ornamented with fine lines in sinuous terraces running parallel to margin outline; lines becoming clearer and denser on genal spine.

Pygidium trapezoidal (excluding spines); axis AMEGHINIANA 47 (4), 2010 prominent with conical outline defined by strong axial furrows, comprising four rings and a terminal piece. First two rings very strong, defined by clear and not very deep furrows; third ring less noticeable (although not always present), with posterior furrow very shallow and only seen in some specimens. Furrows of fourth ring are moderately developed. Terminal piece conical, end rounded. Pleural areas wide and convex, with three conspicuous pleural furrows, apparently coinciding with axis rings and delimiting pygidium spines. Only best preserved specimens showing interpleural furrow coinciding with posterior furrow of first axial ring; small pit visible at its intersection with the axial furrow. Border of pygidium defined by change in slope. Three pairs of robust tubular spines along lateral borders; spines slightly flattened transversally, their length increasing backwards. Posterior pair the longest and the most separated from the rest. Posterior margin of the border showing highest character variation within species; usually straight, but can also be faintly convex, with two pairs of spines or protuberances, or completely smooth. Ornamentation of pygidium consisting of small lines in sinuous terraces on the posterior border and on marginal spines.

Discussion. The main problem arising in any discussion of this genus is that Prozacanthoides stissingensis (Dwight) is the only species of the genus and the illustrations provided by Dwight (1889) are inadequate for any meaningful comparison. In spite of these limitations, strong similarities are observed between our material and P. stissingensis, enough to accommodate our material in Prozacanthoides. Nonetheless, Prozacanthoides zondaensis n. sp. differs from $P$. stissingensis in the tubular marginal spines of the pygidium (in contrast to the flat ones in $P$. stissingensis), and in the longer and more robust posterior pair of spines.

Aguaraya acutispina Rusconi, 1955, type species of Aguaraya Rusconi, 1955, and based on a single pygidium from San Isidro (Mendoza), bears a strong resemblance with the pygidia of the new species. The specimen illustrated by Rusconi (1955) has a pygidium with a similar outline, a prominent axis and three pairs of strong marginal spines, of which the posterior one is the longest (Rusconi, 1955, pl.1, fig. 2). However, it is different from $P$. zondaensis $\mathrm{n}$. sp. in having a relatively shorter axis, a longer posterior edge and two pairs of small spines along the posterior margin. Some of the specimens in our collection bear two protuberances at the posterior margin that could be homologous to the marginal spines of $A$. acutispina (i.e., pl. 2, fig. 9, this contribution). If this were so, both species could be included in the same genus. It is also important to point out that according to Palmer (in litt., 1995), some 
paratypes of $P$. stissingensis show a quadrangular posterior margin with short spinules. A revision of the species of this genus would clarify the relationships among them and identify a possible synonymy.

The material illustrated by Vaccari and Bordonaro 1993 (pl. 1, figs. 10, 12, 13) as Prozacanthoides? sp. and Prozacanthoides n. sp. was also analyzed and compared. Direct observation of the material indicates that the specimen illustrated in figure 10 (CORD-PZ 8729) is congeneric with the material from the La Laja Formation, while the specimens in figures 12 and 13 do not belong to Prozacanthoides, due to the transversal width of the posterior border of the pygidium, and the shape and size of the spines. These specimens are perhaps more closely related to the genus Mexicaspis Lochman, 1948.

Genus Fieldaspis Rasetti, 1951

Type species. Fieldaspis furcata Rasetti, 1951.

Fieldaspis sp.

Figure 5.18-21

1968. ? Fieldaspis cf. F. superba Rasetti; Norford, p. 35, pl. 4, fig. 9, 11 ; pl.5, figs $1-3$

Material examined. Two pygidia, partially preserved. CEGHUNC 23811/CEGH-UNC 23812.

Occurrence. Bed CMEE08, El Estero Member, La Laja Formation, Cerro Molles section.

Description. Pygidium outline trapezoidal (excluding spines). Axis convex, relatively conical, with four distinct rings and terminal piece. Axial furrows sinuous and shallow, deeper at intersection with rings. Pleural fields moderately convex, with three pairs of deep pleural furrows. First pair oriented almost transversally in its proximal part, strongly curving backwards distally. Interpleural furrows shallow. Lateral border furrow wide, essentially delimited by distal deepening of pleural furrows. Border well defined at antero-lateral corner, slightly widened and more concave at postero-lateral corner, reaching backwards into marginal spines. Posterior margin curved and marginal spines strongly oriented backwards, slightly outwards and upwards. External surface covered by small granules on axis and pleural fields, and by anastomosed lines on border.

Discussion. These pygidia can be clearly referred to Fieldaspis Rasetti, 1951, and they are close to F. superba Rasetti (Rasetti, 1951, p. 162, pl. 16, figs. 10-18; Sundberg and McCollum, 2003, p. 343, figs. 11.711.11) in their general shape, and the course and depth of the pleural furrows. Nonetheless, they differ in the outline of the edge, which is oriented back-

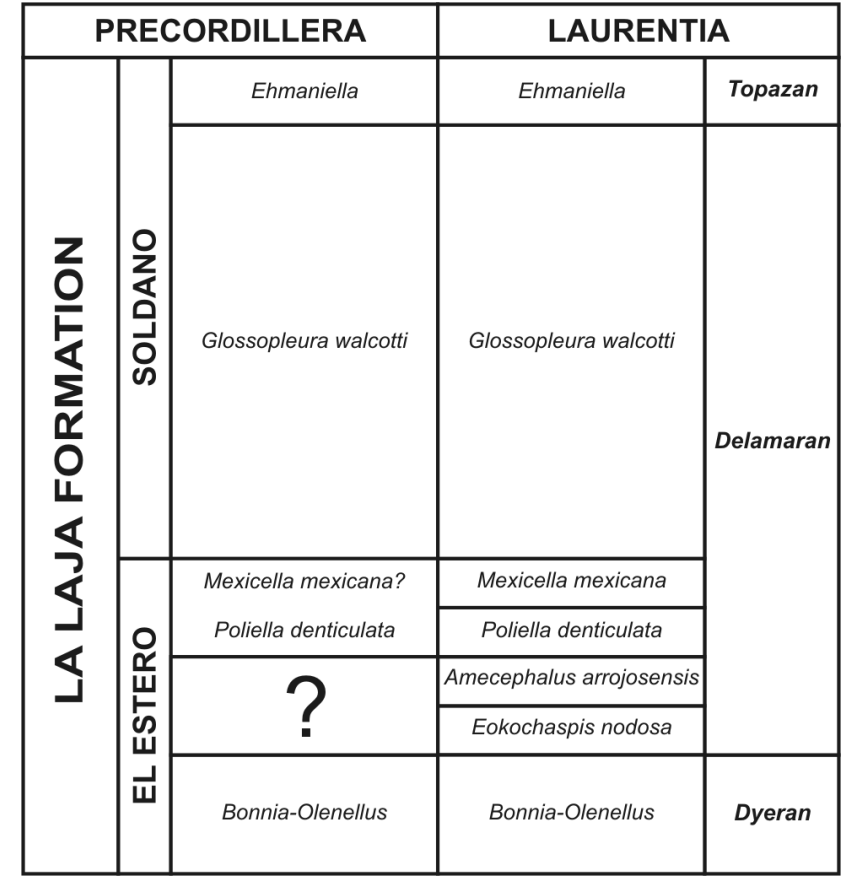

Figure 3. Correlation chart of the litho- and biostratigraphic units from the Eastern Precordillera and Laurentian Middle Cambrian stages and zones proposed by Palmer (1998), Sundberg (2005), and McCollum and Sundberg (2007) / correlación de unidades lito- y bioestratigráficas de Precordillera Oriental con pisos y biozonas del Cámbrico Medio de Laurentia propuestas por Palmer (1998), Sundberg (2005), y McCollum y Sundberg (2007).

wards and slightly inwards in the Argentine species, while it is oriented backwards and outwards and with the marginal spines more outwardly directed in F. superba.

Pygidium of Fieldaspis sp. resembles those of Fieldaspis cf. F. superba Rasetti (Nodford, 1968, p. 35, pl. 5 , figs. 1, 3) in the general outline as well as in the shape of the axis. The only difference is that the first pair of pleural furrows is more transverse in Fieldaspis sp., while in the Canadian specimens it is curved, directed backwards and the axis is narrower posteriorly. It is possible that these materials could be conspecific.

\section{Biostratigraphy}

Cambrian biostratigrapy is based essentially on the distribution of benthic faunas of trilobites. Because of their strong endemism, correlation at an intercontinental scale is difficult and most of the stages within the series have not been established yet. This is why local biostratigraphic frames are widely used in continental correlations. Because of the characteristics of the fauna described here, it will be referred to the schemes established for the Cambrian of Laurentia (see figure 3). The middle Cambrian biostratigraphic schemes for Laurentia were tradi- 


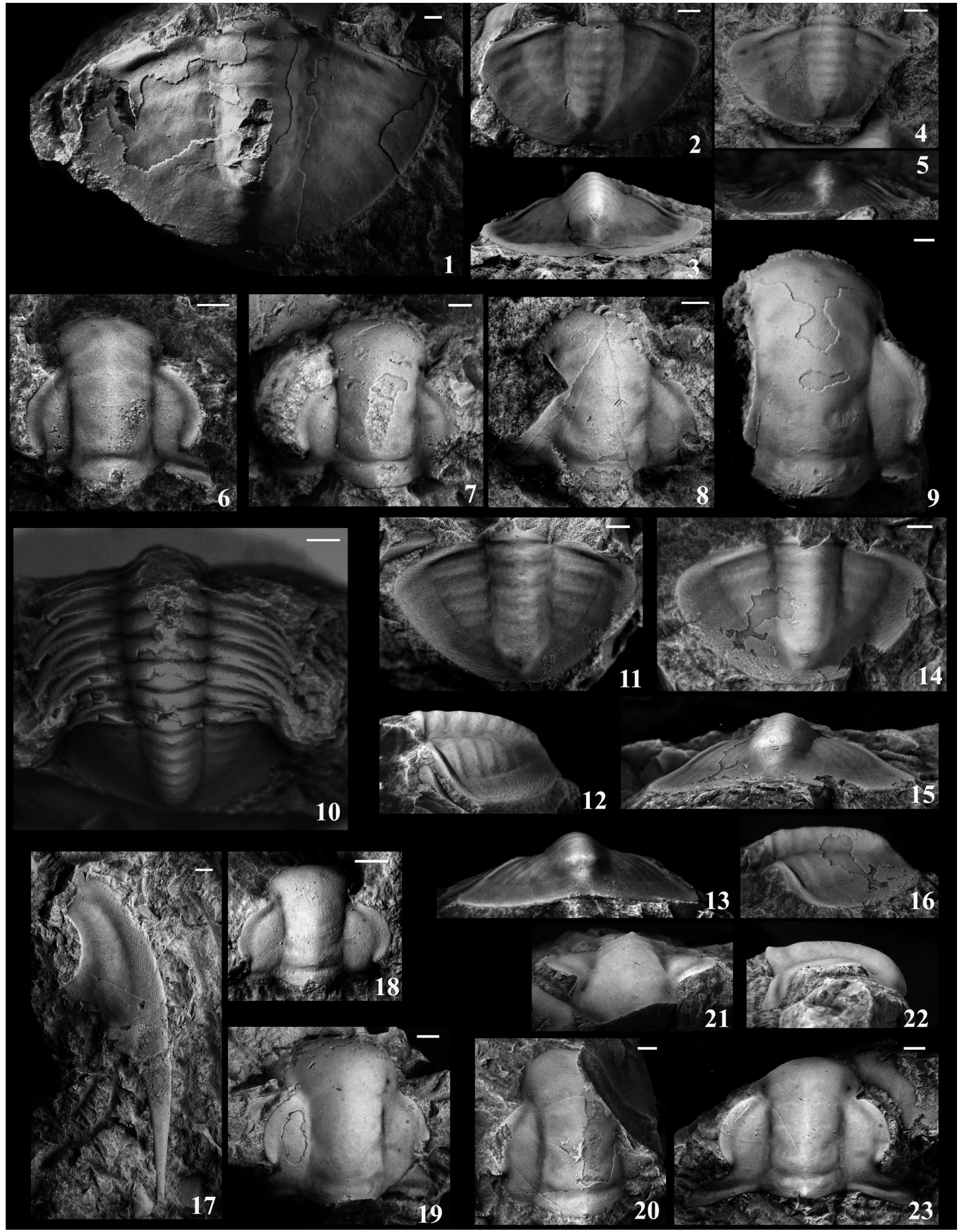

Figure 4. 1-9, Glossopleura lodensis (Clark, 1921), all specimens from La Laja section, Soldano Member / todos los ejemplares de la sección La Laja, Miembro Soldano. 1, pygidium, dorsal view / pigidio, vista dorsal, CEGH-UNC 23790 level LLSL04. 2, 3, pygidium, dorsal and posterior views / pigidio, vistas dorsal y posterior, CEGH-UNC 23805, level LLSL04. 4, 5, pygidium, dorsal and posterior views / pigidio, vistas dorsal y posterior, CEGH-UNC 23793, level LLSL04. 6, cranidium, dorsal view / cranidio, vista dorsal, CEGH-UNC 23800, level LLSL04. 7, cranidium, dorsal view, / cranidio, vista dorsal, CEGH-UNC 23796, level LLSL04. 8, librigena, dorsal view / mejilla libre, vista dorsal, AMEGHINIANA 47 (4), 2010 
tionally defined based on the occurrence of a single genus or genera association (Rasetti, 1951; Lochman and Wilson, 1958). During the last decades, biostratigraphic research of great detail was undertaken mainly by Sundberg (1994), Eddy and McCollum (1998), Sundberg and McCollum (2000, 2003), McCollum and Sundberg (2007) among others. These contributions represent a source of abundant and detailed data on the different successions and faunal associations of Laurentian localities. Moreover, these authors proposed more precise biostratigraphic schemes based on species or species associations.

Trilobites of the La Laja Formation allow recognition of the Delamaran Stage. This stage was postulated by Palmer (1998) for the interval of the Corynexochid biomere and represents the first stage of the Lincolnian Series of the Cambrian of Laurentia. The base of this stage, in its type section -Delamar Mountains, eastern Nevada (Pioche Shale)- is characterized by the presence of abundant silicified specimens of Eokochaspis nodosa (Sundberg and McCollum, 2000). The upper boundary of the stage is defined by the occurrence of Proehmaniella basilica (Resser, 1945) at the base of the Proehmaniella Subzone of the Ehmaniella Zone that defines the base of the next stage, i.e., the Topazan (Sundberg, 2005). Trilobites so far recorded in the Delamaran Stage are ptychoparids related to Kochaspis Resser, 1935, and corynexochids of the families Zacanthoididae and Dolichometopidae (Palmer, 1998). The zones established for this stage are: Eokochaspis nodosa Zone, Amecephalus arrojosensis Zone, Poliella denticulata Zone, Mexicella mexicana Zone and Glossopleura walcotti Zone. The zones of Poliella denticulata, Mexicella mexicana (possibly) and Glossopleura walcotti are recognized in the La Laja Formation. A scheme of the zones recognized in the La Laja Formation is shown in figure 3.

\section{Poliella denticulata Zone}

Recently, and after a series of papers focused mainly on the lower part of the Middle Cambrian, Sundberg and McCollum (1997, 2000, 2002, 2003) defined - in the Eastern region of Nevada - three zones located between the last record of olenellids and the base of the Mexicella mexicana Zone. These are, in ascending order, Eokochaspis nodosa Zone, Amecephalus arrojosensis Zone and Poliella denticulata Zone. The authors also subdivided the youngest of these zones into five different faunal assemblages, i.e., the Poliella denticulata, Fieldaspis celer, Syspacephalus longus, Poliellaites gloriosa, and Kochiella augusta assemblages. It is important to point out that species of Fieldaspis (see Rasetti, 1951) occur in three of the five assemblages mentioned and that these species are practically restricted to the $P$. denticulata Zone. In this contribution we document the record of Fieldaspis sp. at Cerro Molles. Some specimens collected twenty meters below the first record of Prozacanthoides at Quebrada La Laja are very close to Fieldaspis bilobata Rasetti, 1951. Yet, because of the scarce and relatively poorly preserved material (one pygidium and one cranidium), its assignment remains uncertain. Fieldaspis sp., from the top of El Estero Member (Cerro Molles section), closely resembles Fieldaspis cf. superba Norford, 1968, and they are probably conspecific. Fieldaspis superba Rasetti, 1951, was recorded in the Pioche Shale, in the Kochiella augusta association, according to the scheme of Sundberg and McCollum (2003). According to the authors this association would be the equivalent to Kochaspis Zonule defined by Palmer and Halley (1979) in the Carrara Formation.

In the La Laja Formation, Fieldaspis sp. constitutes -along with an association dominated by ptychoparids- the earliest Middle Cambrian fauna recorded to date in Eastern Precordillera. The occurrence of Fieldaspis sp. in Cerro Molles allows us to infer the presence of the Poliella denticulata Zone at the top of El Estero Member. However, we can not determine with certainty to which zonule or assemblages our material belongs. It is important to mention that Rasetti (1957) suggested a lineage including F. bilobata Rasetti, 1951, F. furcata Rasetti, 1951, F. celer (Walcott, 1917) and F. superba Rasetti, 1951. Likewise, Sundberg and McCollum (2003) found a morphologic gradient along the three species of Fieldaspis in the Pioche Shale (F. bilobata, F. celer and F. superba) that further supported the idea of Rasetti. The morphologic gradient suggested by both authors

CEGH-UNC 23807, level LLSL05. 9, cranidium, dorsal view / cranidio, vista dorsal, CEGH-UNC 23808, level LLSL04. 10-23, Glossopleura walcotti Poulsen, 1927, all specimens from La Laja section, Soldano Member / todos los ejemplares de la sección La Laja, Miembro Soldano. 10, thorax, dorsal view / tórax, vista dorsal, CEGH-UNC 23692, level LLSL02. 11-13, pygidium, dorsal, lateral and posterior views / pigidio, vistas dorsal, lateral y posterior, CEGH-UNC 23731, level LLSL03. 14-16, pygidium, dorsal, posterior and lateral views / pigidio, vistas dorsal, posterior y lateral, CEGH-UNC 23730, level LLSL03. 17, librigena, dorsal view / mejilla libre, vista dorsal, CEGH-UNC 23693, level LLSL03. 18, cranidium, dorsal view / cranidio, vista dorsal, CEGH-UNC 23721, level LLSL03. 19, cranidium, dorsal view / cranidio, vista dorsal, CEGH-UNC 23701, level LLSL03. 20, cranidium, dorsal view / cranidio, vista dorsal, CEGH-UNC 23687, level LLSL03. 21-23, cranidium, anterior, lateral and dorsal views / cranidio, vistas anterior, lateral y dorsal, CEGH-UNC 23697, level LLSL03. Scale bar is $1 \mathrm{~mm} /$ escala gráfica: $1 \mathrm{~mm}$. 


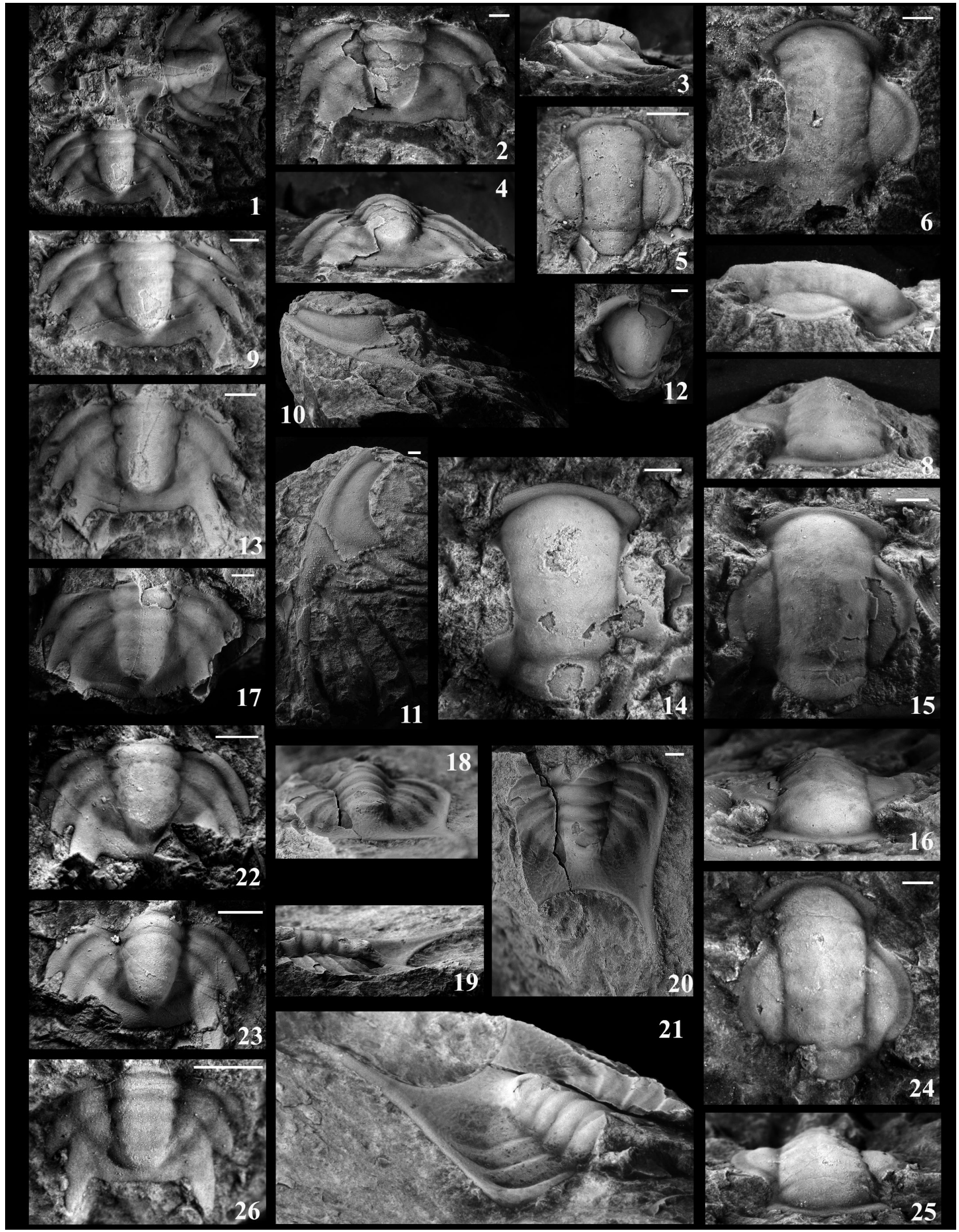

Figure 5. 1-17, 22-26, Prozacanthoides zondaensis n. sp., all specimens from La Laja section and level LLEE04 / todos los ejemplares de la sección La Laja, nivel LLEE04. 1, pygidia, top: dorsal view of CEGH-UNC 23641; bottom: dorsal view of CEGH-UNC 23640/ pigidios, arriba: vista dorsal de CEGH-UNC 23641; abajo: vista dorsal de CEGH-UNC 23640. 2-4, pygidium, dorsal, lateral and posterior views / pigidio, vistas dorsal, lateral y posterior, CEGH-UNC 23671. 5, cranidium, dorsal view / cranidio, vista dorsal, CEGH-UNC 23666. 6-8, cranidium, dorsal, lateral and anterior views / cranidio, vistas dorsal, lateral y anterior, CEGH-UNC 23670. 9, pygidium, dorsal view / pigidio, vista dor- 
consists of a progressive transformation occurring in the posterior margin of the pygidia, from a clearly bilobed margin in F. bilobata at one end, to the strong pair of spines in F. superba at the other. The intermediate stages could be represented by $F$. furcata and $F$. celer. Each species of Fieldaspis identified in the Pioche Shale belongs to a different assemblage, and the morphologic succession coincides with younger assemblages. Since the material from Precordillera shows a strong resemblance to $F$. superba, it is possible to suggest that the studied assemblages could be correlated with the Kochiella augusta association. Study of the ptychoparids associated with Fieldaspis at Cerro Molles should help to confirm or reject this tentative correlation.

According to data available up to now, Fieldaspis $\mathrm{sp}$. is the only clear representative of the Poliella denticulata Zone in Precordillera, and its record is restricted to the upper levels of the El Estero Member at Cerro Molles. Although this restriction prevents further correlations with other localities from Precordillera, it becomes a very valuable tool when correlating with Laurentian localities. In this sense we can affirm that the top levels of the El Estero Member (Cerro Molles section) bearing Fieldaspis sp. (Poliella denticulata Zone), can be correlated with those that yield Fieldaspis cf. F. superba in the Mackenzie district, northeastern Canada (Norford, 1968); and with the ones that contain Fieldaspis superba (Fieldaspis superba faunule of the Plagiura-Kochaspis Zone) in the Mount Whyte Formation in Alberta, Canada (Rasetti, 1951). Likewise, the levels with Fieldaspis sp. of the La Laja Formation can be correlated with the blocks assigned to the top of the Cap Kent Formation in northeastern Greenland (Poulsen, 1964); and with the levels that contain Fieldaspis superba at the top of the Poliella denticulata Zone in the Pioche Shale Formation, Nevada (Sundberg and McCollum, 2003).

\section{Mexicella mexicana Zone}

The Mexicella mexicana Zone (McCollum and Sundberg, 2007) was recently defined in replacement of the Albertella Zone (Deiss, 1939), a criterion that is shared here. In the Grassy Springs Member of the Pioche Shale, Nevada, Eddy and McCollum (1998) recognized three distinctive associations, i.e., Albertellina espinosa Subzone, a middle unnamed subzone, and Albertella highlandensis Subzone. This subdivision corresponds to three different assemblages that do not reflect a temporal succession, but a particular spatial distribution in the basin. Palmer (in Palmer and Halley, 1979) proposed a similar scheme for the same interval in the Carrara Formation where the Albertella Zone was subdivided in three faunules, i.e., Ogygopsis faunule, Zacanthoidid faunule, and Albertella-Mexicella faunule. However, McCollum and Sundberg (2007) disagreed with the stratigraphic relationships suggested for these associations, and placed the Ogygopsis Zonule and the temporally equivalent Zacanthoidid Zonule between the uppermost Mexicella mexicana Zone and the lowermost Glossopleura walcotti Zone.

The M. mexicana Zone cannot be recognized with certainty in the La Laja Formation. In the upper part of the El Estero Member exposed at Quebrada La Laja a trilobite association dominated by Prozacanthoides is recorded. This genus does not have a distinctive position in the biostratigraphic schemes of Laurentia. This is because at the single locality where it is found it is the only representative of the Middle Cambrian, rendering impossible to determine its relative position with respect to the other zones of the same age (Palmer and James, 1979). Furthermore, no diagnostic element of this trilobite zone has been recognized in the preliminary study of the ptychopariids, dorypygids and zacanthoidids associated with $P$. zondaensis at Quebrada La Laja. In any event, Prozacanthoides zondaensis $\mathrm{n}$. $\mathrm{sp}$. is found in the La Laja Formation below the first record of the Glossopleura walcotti Zone and $20 \mathrm{~m}$ above the record of Fieldaspis sp. Therefore this association could yet correspond to the Poliella denticulata Zone or else represent the M. mexicana Zone. If the latter alternative were correct, then the restricted development of the Mexicella mexicana Zone in the La Laja Formation (as well as the one in the Poliella denticulata Zone) significantly contrasts, for instance, with what was documented for the Pioche Shale in Nevada. Possibly, this particular record in the Precordillera is a result of the presence of a condensed interval, a hiatus in the record, or a combination of both factors.

The beds with Prozacanthoides zondaensis n. sp.,

sal, CEGH-UNC 23640, holotype / holotipo. 10, 11, librigena, lateral and dorsal views / mejilla libre, vistas lateral y dorsal, CEGH-UNC 23637. 12, hypostome, ventral view / hipostoma, vista ventral, CEGH-UNC 23685. 13, pygidium, dorsal view / pigidio, vista dorsal, CEGHUNC 23641. 14, cranidium, dorsal view / cranidio, vista dorsal, CEGH-UNC 23676. 15, 16, cranidium, dorsal and anterior views / cranidio, vistas dorsal y anterior, CEGH-UNC 23664. 17, pygidium, dorsal view / pigidio, vista dorsal, CEGH-UNC 23638. 22, pygidium, dorsal view / pigidio, vista dorsal, CEGH-UNC 23642. 23, pygidium, dorsal view / pigidio, vista dorsal, CEGH-UNC 23658. 24, 25, cranidium, dorsal and anterior views / cranidio, vistas dorsal y anterior, CEGH-UNC 23665. 26, pygidium, dorsal view / pigidio, vista dorsal, CEGH-UNC 23667. 18-21, Fieldiaspis sp., Cerro Molle section, level CMEE08 / sección Cerro Molle, nivel CMEE08. 18-21, pygidium, posterior, lateral, dorsal and anterolateral views / pigidio, vistas posterior, lateral y antero-lateral, CEGH-UNC 23811. Scale bar is $1 \mathrm{~mm} /$ escala gráfica: $1 \mathrm{~mm}$. 
from the upper part of the El Estero Member at Quebrada La Laja, are correlated with those that bear Prozacanthoides? documented by Vaccari and Bordonaro (1993) in the block within the olisthostrom of the Los Sombreros Formation (at Río Jáchal). The levels with Prozacanthoides in the La Laja Formation are correlated with the levels that yield Prozacanthoides stissingensis (Dwight) Dutchess County, New York. It is important to note that the sucession exposed at the latter locality has been referred to the Middle Cambrian with no further precisions (Landing, 2007). Accordingly, taking into account the correlation herein proposed, Dwight's locality could be placed below the Glossopleura Zone - between the uppermost part of the $P$. denticulada and possibly the M. mexicana Zones.

\section{Glossopleura walcotti Zone}

Rasetti (1951) analyzed the faunas of the Middle Cambrian of Alberta and British Columbia and identified three different faunules in the Glossopleura Zone, i.e., Glossopleura merlinensis faunule, Glossopleura boccar faunule, and Polypleuraspis insignis faunule. Some of the species in these faunules were later considered synonyms and others are just found at their type localities; therefore use of this scheme in other regions is uncertain. The Glossopleura Zone in northeastern Greenland was subdivided by Poulsen (1964) into two different faunules, i.e., Glossopleura faunule and Clavaspidella faunule. Within the Glossopleura faunule are found the three faunules identified by Rasetti (1951) for Alberta. We do not agree with the criteria used by Poulsen (1964) when he included the Clavaspidella faunule within the Glossopleura Zone. Instead it may be more closely related to the Ehmaniella Zone. Sundberg (2005) documented the Glossopleura Zone in the Chisholm Formation, Utah, based on a record of Glossopleura boccar. Finally, McCollum and Sundberg (2007) revised the zonation of the Delamaran of the Great Basin and defined the Glossopleura walcotti Zone, by the FAD of Glossopleura walcotti Poulsen (1927).

Glossopleura walcotti is one of the best represented zones in the Precordilleran La Laja Formation. It has been recorded at the Quebrada La Laja section (five levels), the Esteros de Zonda section (two levels), and the Cerro Molles section (two levels), becoming the main element for correlation among the different sections of the lower Middle Cambrian of the La Laja Formation. These records are associated -at the three sections- to a noticeable lithofacial change. This change takes place a few meters above a surface interpreted as transgressive by Keller (1999). In general, it coincides with the base of the Soldano Member in the studied localities.

AMEGHINIANA 47 (4), 2010
The beds carrying the fauna assigned to the Glossopleura walcotti Zone in the La Laja Formation are correlated with part of the blocks of Ojos de Agua and Los Ratones in Western Precordillera, which bear Glossopleura sp. and Glossopleura aff. leona (Bordonaro and Banchig, 1990, 1996). In Laurentia the Glossopleura walcotti Zone is widely distributed. The levels with Glossopleura walcotti documented in the Soldano Member of the La Laja Formation are correlated with those bearing the same species in the Cap Wood Formation in northeastern Greenland (Poulsen, 1964). They are also correlated with the ones that contain G. walcotti in the Carrara Formation (Palmer and Halley, 1979).

\section{Biogeographic considerations}

The Precordillera has faunal and tectosedimentary features that are notably different from other Paleozoic successions along the western margin of South America. These peculiar characteristics led different authors to formulate hypotheses explaining the presence of this terrane in western Argentina. Nowadays, and on the basis of stratigraphic (e.g., Bond et al., 1984; Astini et al., 1995, 1996; Thomas and Astini, 1999), paleomagnetic (Rapalini and Astini, 1998), and faunal evidence (Vaccari, 1994; Benedetto, 2004) there is widespread consensus on the Laurentian origin of Precordillera. Nevertheless, other authors are inclined towards a parautochthonus origin respect of the margin of Gondwana (e.g., Baldis et al., 1989; Loske, 1993; Aceñolaza et al., 2002; Finney, 2007).

Benedetto et al. (2009) analysed the biogeographic affinities of the early Paleozoic faunas of the Precordillera. Particularly, they suggest that trilobite evidence throughout the entire Cambrian succession of Precordillera points towards a strong faunal identity with Laurentia, and at the same time towards the absence of faunal exchange with coetaneous areas of East Gondwana. Besides, Precordilleran trilobites are mostly recorded in shallow environmental settings. It is widely accepted that "inshore biofacies" are mostly confined to a single palaeocontinent (Fortey and Owens, 1978, 1987) and, hence, these associations are among the best biogeographic markers. In the parautochthonous model proposed by Aceñolaza et al. (2002) and recently reviewed by Finney (2007), during the Cambrian the Precordillera is located adjacent to the margin of Gondwana, close to Antarctica and Australia. According to this model Antarctica, Australia, and Precordillera were in a similar latitudinal position, with carbonate platforms developed over all three areas, and no oceanic barriers separating them. As is well known, Cambrian faunas from Antarctica and Australia are closely re- 
lated and belong to the Redlichiid Realm, whereas no faunal elements of this realm are shared with Precordillera. If the Precordillera and AntarcticaAustralia platforms were connected as depicted in the parautochthonous reconstruction by Finney (2007, fig. 5), a fluid faunal exchange among these blocks should be expected in both directions. Finney (2007) argues that the westward direction of equatorial oceanic currents is responsible for the lack of tropical Gondwanan elements in the Precordillera. However, during Furongian-Tremadocian times active larval dispersion into the Andean platforms from Australia, New Zealand and South China is well documented (Vaccari et al., 2006; Vaccari and Waisfeld, 2008). If Cuyania was adjacent to Gondwana, as Aceñolaza et al. (2002) and Finney (2007) proposed, a question remains that needs to be explained using biogeographic arguments: why are faunal affinities of Precordillera exclusively Laurentian until the Tremadocian?. On the other hand, if Laurentian faunas were carried into the Precordillera by west-flowing equatorial currents (Finney, 2007, fig. 10) it is hard to explain why they did not reach the East-Gondwanan carbonate platforms.

One of the arguments used to sustain the parautochthonus model and refute the allochthonous one is based on the comparison of faunal diversity between the Middle Cambrian of Laurentia and Precordillera (Finney et al., 2005; Finney, 2007). From our perspective, this is an inappropriate comparison not only because of the difference in scale (the whole oriental margin of Laurentia against Precordillera), but also because of the great variety of environments present in the different Laurentian localities which have not been recorded in Precordillera. Accordingly, the supposed difference in diversity between the faunas of Precordillera and Laurentia is largely a sampling artifact. One hundred years of intense research in Laurentia against a stage of incipient study of the Cambrian faunas of Precordillera additionally explain this sampling bias. Recent studies (Foglia and Vaccari, 2006a, 2006b; Bordonaro et al., 2008; Benedetto et al., 2009) and the present contribution provide new elements to assess the different contrasting arguments. The genera documented in this work for the Delamaran of the La Laja Formation (Fieldaspis, Prozacanthoides and Glossopleura), as well as those documented by Bordonaro (Bordonaro et al., 2008; Bordonaro and Pratt, 2008a) for other intervals in the La Laja Formation are characteristic of -and restricted to- Laurentia. It is important to point out that neither the allochthonous model nor the parautochthonus one question the affinities of the faunas of Precordillera with those of Laurentia. The differences between these models surface when it comes to explaining the presence of this fauna in Precordillera.
Clearly, the most parsimonious interpretation is to place the Precordillera terrane close to Laurentia.

\section{Conclusions}

The trilobite faunas collected in the limestones of the La Laja Formation allow referring the lower third of the Soldano Member and the upper part of the El Estero Member to the Delamaran Stage. The Poliella denticulata, Mexicella mexicana? and Glossopleura walcotti zones are present in this interval. The taxa that enabled identification of these zones are: Fieldaspis sp., G. walcotti and G. lodensis.

The restricted development of the $P$. denticulada Zone and the uncertainty about the record of the $M$. mexicana Zone in the El Estero Member suggest either the record of a condensed section or a hiatus at the contact with the Soldano Member.

Correlations were established between the $\mathrm{La}$ Laja Formation and different Laurentian lithostratigraphic units, as well as with blocks of Western Precordillera. Because of their age, these blocks could represent lateral equivalents of the La Laja Formation. According to Gómez and Astini (2006), some of them constitute the only record of relatively deep facies and can be used to reconstruct at least partially the Precordilleran platform during the Middle Cambrian.

The fauna illustrated in this work has undeniable Laurentian affinities. Further and detailed studies of the entire fauna from the La Laja Formation will be a key to establish the location of Precordillera with greater precision in paleogeographic reconstructions, and also in determining the timing of the inferred break-away from Laurentia.

\section{Acknowledgments}

The manuscript benefited from critical comments by reviewers S. Peng, F. Sundberg, and F. Tortello. Funding for this contribution was provided by ANPCyT-FONCyT (PICT 2006, 1272) and PICT 11741.

\section{References}

Aceñolaza, F.G. and Toselli, A.J. 2007. Evolución del borde Gondwánico de Argentina en el Paleozoico: Cuyania, ¿Un fragmento Gondwánico o un alóctono Lauréntico? 4th European Meeting on the Palaeontology and Stratigraphy of Latin America. Cuadernos del Museo Geominero 8: 3-8.

Aceñolaza, F.G., Miller, H. and Toselli, A.J. 2002. ProterozoicEarly Paleozoic evolution in western South America - a discussion. Tectonophysics 354: 121-137.

Astini, R.A. 1998. Stratigraphical evidence supporting the rifting, drifting and collision of the Laurentian Precordillera terrane of western Argentina. In: R.J. Pankhurst and C.W. Rapela, 
(eds.), The Proto-Andean margin of Gondwana, Geological Society Special Publication 142: 11-33.

Astini, R.A. and Vaccari, N.E. 1996. Sucesión evaporítica del Cámbrico Inferior de la Precordillera: Significado geológico. Revista de la Asociación Geológica Argentina 51: 97-106.

Astini, R.A., Benedetto, J.L. and Vaccari, N.E. 1995. The early Paleozoic evolution of the Argentine Precordillera as a Laurentian rifted, drifted, and collided terrane: A geodynamic model. Bulletin of the Geological Society of America 107: 253273.

Astini, R.A., Ramos, V.A., Benedetto, J.L., Vaccari, N.E. and Cañas, F.L. 1996. La Precordillera: Un terreno exótico a Gondwana. $13^{\circ}$ Congreso Geológico Argentino and $3^{\circ}$ Congreso de Exploración de Hidrocarburos (Buenos Aires), Actas 5: 293-324.

Baldis, B.A. and Bordonaro, O.L. 1981. Evolución de facies carbonáticas en la cuenca Cámbrica de la Precordillera de San Juan. $8^{\circ}$ Congreso Geológico Argentino (San Luis), Actas 2: 385-397.

Baldis, B.A., Peralta, S. and Villegas, R. 1989. Esquematizaciones de una posible transcurrencia del terrane de Precordillera como fragmento continental procedente de áreas pampeanobonaerenses. Instituto Superior de Correlación Geológica 5: 81-100.

Benedetto, J.L. 2004. The allochthony of the Argentine Precordillera ten years later (1993-2003): A new paleobiogeographic test of the microcontinental model. Gondwana Research 7: 1027-1039.

Benedetto, J.L., Vaccari N.E., Waisfeld, B.G., Sánchez T.M. and Foglia, R.D. 2009. Cambrian and Ordovician biogeography of the South American margin of Gondwana and accreted terranes. In: M.G. Basset (ed.), Early Paleozoic Peri-Gondwana Terranes: New Insights from Tectonics and Biogeography. Geological Society of London, Special Publications 325: 201-232.

Bond, G.C., Nickeson, P.A. and Kominz, M.A. 1984. Breakup of a supercontinent between $625 \mathrm{Ma}$ and $555 \mathrm{Ma}$ : New evidence and implications for continental histories. Earth and Planetary Science Letters 70: 325-345.

Bordonaro, O.L. 1980. El Cámbrico en la quebrada de Zonda, Provincia de San Juan. Revista de la Asociación Geológica Argentina 35: $26-40$.

Bordonaro, O.L. 1986. Bioestratigrafía del Cámbrico Inferior de San Juan. $9^{\circ}$ Congreso Argentino de Paleontología y Bioestratigrafía (Mendoza), Actas 1: 19-27.

Bordonaro, O.L. 2003a. Evolución paleoambiental y paleogeográfica de la cuenca cámbrica de la Precordillera argentina. Revista de la Asociación Geológica Argentina 58: 329-346.

Bordonaro, O.L. 2003b. Review of the Cambrian Stratigraphy of the Argentine Precordillera. Geologica Acta 1: 11-21.

Bordonaro, O.L. and Banchig, A. 1990. Nuevos trilobites del Cámbrico Medio en la Quebrada Ojos de Agua, Sierra del Tontal, San Juan. $5^{\circ}$ Congreso Argentino de Paleontología y Bioestratigrafía (Tucumán), Actas: 31-37.

Bordonaro, O.L. and Banchig, A. 1995. Trilobites laurénticos en el Cámbrico de la Precordillera argentina. $6^{\circ}$ Congreso Argentino de Paleontología y Bioestratigrafía (Trelew), Actas: 59-65

Bordonaro, O.L. and Banchig, A. 1996. Estratigrafía de los olistolitos cámbricos de la Precordillera argentina. $13^{\circ}$ Congreso Geológico Argentino (Buenos Aires), Actas 5: 471-479.

Bordonaro, O.L. and Pratt, B.R. 2008a. Bioestratigrafía de la Formacion La Laja (Cámbrico Inferior-Cámbrico Medio), Precordillera Oriental de San Juan. $17^{\circ}$ Congreso Geológico Argentino (Jujuy), Actas 3: 989.

Bordonaro, O.L. and Pratt, B.R. 2008b. Middle Cambrian trilobites of La Laja Formation, Western Argentina. In: I. Rábano, R. Gozalo and D. Garcia-Bellido (eds.), Advances in trilobite research. Cuadernos del Museo Geominero 9: 55-56.

Bordonaro, O.L., Banchig, A.L., Pratt, B.R. and Raviolo, M.M. 2008. Trilobite-based biostratigraphic model (biofacies and biozonation) for the middle Cambrian carbonate platform of the Argentine Precordillera. Geologica Acta 6: 111-125.

Borrello, A.V. 1962. Caliza La Laja (Cámbrico medio de San Juan). Notas Comunicaciones Investigaciones Científicas (La Plata) 2: 3-8.
Borrello, A.V. 1963. Fremontella inopinata n. sp. del Cámbrico de Argentina. Ameghiniana 3: 51-55.

Clark, C.W. 1921. Lower and Middle Cambrian formations of the Mohave Desert: California. University of California Publications in Geological Sciences 13: 1-7

Deiss, C. 1939. Cambrian formations of southwestern Alberta and southestern British Columbia. Bulletin of the Geological Society of America 50: 951-1026

Dwight, W.D. 1889. Recent Explorations in the Wappinger, Valley Limestones and other formations of Dutchess Co., N.Y. American Journal of Science $3^{\circ}$ series 28: 139-149.

Eddy, J.D. and McCollum, L.B. 1998. Early middle Cambrian Albertella Biozone trilobites of the Pioche Shale, southeastern Nevada. Journal of Paleontology 72: 864-887.

Finney, S.C. 2007. The parautochthonous Gondwanan origin of the Cuyania (greater Precordillera) terrane of Argentina: A reevaluation of evidence used to support an allochthonous Laurentian origin. Geologica Acta 5: 127-158.

Finney, S.C., Gleason, J.D., Gehrels, G.G., Peralta, S.H. and Aceñolaza, G. 2003. Early Gondwanan Connection for the Argentine Precordillera Terrane. Earth and Planetary Sciences Letters 205: 349-359.

Finney, S.C., Peralta, S., Gehrels, G. and Marsaglia, K. 2005. The Early Paleozoic history of the Cuyania (greater Precordillera) terrane of western Argentina: evidence from geochronology of detrital zircons from middle Cambrian sandstones. Geologica Acta 3: 339-354.

Foglia, R.D. and Vaccari, N.E. 2006a. El Género Bonnima Fritz, en el Cerro Molle, Sierra de Villicum, San Juan. Significado bioestratigráfico. $9^{\circ}$ Congreso Argentino de Paleontología y Bioestratigrafía (Córdoba), Actas: 159.

Foglia, R.D. and Vaccari N.E. 2006b. La Biozona de Glossopleura (Delamariano Cámbrico Medio en el Miembro Soldano, Formación La Laja, San Juan, Argentina. $9^{\circ}$ Congreso Argentino de Paleontología y Bioestratigrafía (Córdoba), Actas: 158.

Fortey, R.A. and Owens, R. 1978. Early Ordovician (Arenig) stratigraphy and faunas of the Carmarthen district, southwest Wales. Bulletin of the British Museum (Natural History) Geology 30: 226-294.

Fortey, R.A. and Owens, R.M. 1987. The Arenig Series in South Wales: Stratigraphy and paleontology. Bulletin of the British Museum (Natural History) Geology 41: 69-307.

Gómez, F.J. and Astini, R.A. 2006. Sedimentología y paleoambientes de la Formación La Laja (Cámbrico), Quebrada La Laja, Sierra Chica de Zonda, San Juan, Argentina. Revista Geologica de Chile 33: 19-46.

Harrington, H.J. and Leanza, A.F. 1943. Paleontología del Paleozoico Inferior de la Argentina. 1. Las Faunas del Cámbrico Medio de San Juan. Revista del Museo de La Plata (2), Sección Paleontológica 11: 207-223.

Kayser, A. 1876. Über primordiale and untersilurische Fossilien aus der argentinischen Republik. Palaeontographica (Berlin), suppl, 3, Lief. 2: 1-33.

Keller, M. 1999. Argentine Precordillera: Sedimentary and plate tectonic history of a Laurentian crustal fragment in South America. Geological Society of America, Special Paper 431: 1-131.

Landing, E. 2007. Ediacaran-Ordovician of East Laurentia Geologic Setting and Controls on Deposition along the New York Promontory Region. New York State Museum Bulletin: 510: 5-24. .

Leanza, A.F. 1947. El Cámbrico Medio de Mendoza. Revista del Museo de La Plata (nueva serie) 3 Paleontología 17: 223-237.

Lochman, C. 1948. New Cambrian trilobite genera from northwest Sonora, Mexico. Journal of Paleontology 22: 451-464.

Lochman-Balk, C. and Wilson, J.L. 1958. Cambrian biostratigraphy in North America. Journal of Paleontology 32: 312-350.

Loske, W.P. 1993. La Precordillera del Oeste Argentino: una cuenca de back arc en el Paleozoico. $12^{\circ}$ Congreso Geológico Argentino y $2^{\circ}$ Congreso de exploración de Hidrocarburos (Mendoza), Actas 1: 5-15. 
McCollum L.B. and Sundberg F.A. 2007. Cambrian trilobite biozonation of the Laurentian Delamaran Stage in the southern Great Basin, U.S.A.: Implications for global correlations and defining a Series 3 global boundary stratotype: In J.R. Laurie and J.R. Paterson (eds.), Papers in honour of John H. Shergold 1938-2006. Memoir 34 of the Association of Australsian Palaeontologists, pp. 147-156.

Norford, B.S. 1968. A middle Cambrian Plagiura-Poliella Faunule from Southwest District of Mackenzie. Geological Survey of Canada, Bulletin 163: 29-38.

Palmer, A.R. 1998. A proposed nomenclature for stages and series for the Cambrian of Laurentia. Canadian Journal Earth Science 35: 323-328.

Palmer, A.R. and James N.P. 1979. The Hawke Bay Event: A circum Iapetus regression event near the lower-middle Cambrian boundary. International Geological Correlation Program Meeting (Blacksburg, Virginia), pp. 1-3.

Palmer, A.R. and Halley, R.B. 1979. Physical stratigraphy and trilobite biostratigraphy of the Carrara Formation (lower and middle Cambrian) of the southern Great Basin. U.S. Geological Survey Professional Paper 1047: 1-131.

Poulsen, C. 1927. The Cambrian, Ozarkian and Canadian Faunas of Northwest Greenland. Meddelelser om Grønland 70: 233-343.

Poulsen, V. 1958. Contributions to the middle Cambrian paleontology and stratigraphy of Argentina. Museum Mineralogy Geology University Copenhague, Comunication Paleontology 103: 1-22.

Poulsen, V. 1964. Contribution to the lower and middle Cambrian poleontology and stratigraphy of northwest Greenland. Meddelelser om Grønland 164: 1-105.

Rapalini, A.E. and Astini, R.A. 1998. Paleomagnetic confirmation of the allochthony of the Argentine Precordillera. Earth and Planetary Science Letters 155: 1-14.

Rasetti, F.D. 1951. Middle Cambrian stratigraphy and faunas of the Canadian Rocky Mountains. Smithsonian Miscellaneous Collections 128: 1-35.

Rasetti, F.D. 1957. Additional fossils from the middle Cambrian Mt. Whyte Formation of the Canadian Rocky Mountains. Journal of Paleontology 31: 955-972.

Resser, C.E. 1928. Cambrian fossils from the Mohave Desert. Smithsonian Miscellaneous Collections 81: 1-14.

Resser, C.E. 1935. Nomenclature of some Cambrian trilobites. Smithsonian Miscellaneous Collections 95: 1-46.

Resser, C.E. 1937. Third contribution to nomenclature of Cambrian trilobites. Smithsonian Miscellaneous Collections 95: 1-29.

Resser, C.E. 1945. Cambrian history of the Grand Canyon region, Part 2. Cambrian fossils of the Grand Canyon. Carnegie Institution of Washington Publication 563: 171-220.

Rusconi, C. 1945. Trilobites silúricos de Mendoza. Anales de la Sociedad Científica Argentina 139: 216-219.

Rusconi, C. 1955. Fosiles Cámbricos y Ordovicicos al Oeste de San Isidro, Mendoza. Revista del Museo de Historia Natural de Mendoza 8: 1-4.

Stelzner, A. 1923-1924. Contribuciones a la Geología de la Republica Argentina. Actas de la Academia Nacional de Ciencias (Córdoba) 1- 2: 1-228.

Sundberg, F.S. 1994. Corynexochida and Ptychopariida (Trilobita, Arthropoda) of the Ehmaniella Biozone (middle Cambrian), Utah and Nevada. Natural History Museum of Los Angeles County, Contributions in Science 446: 1-137.
Sundberg, F.S. 2005. The Topazan stage, a new Laurentian stage (Lincolnian Series-"Middle" Cambrian). Journal of Paleontology 79: 63-71.

Sundberg, F.S. and McCollum, L.B. 1997. Oryctocephalids (Corynexochida: Trilobita) of the Lower-Middle Cambrian boundary interval from California and Nevada. Journal of Paleontology 71: 1065-1090.

Sundberg, F.S. and McCollum, L.B. 2000. Ptychopariid Trilobites of the Lower-Middle Cambrian boundary interval, Pioche Shale, southeastern Nevada. Journal of Paleontology 74: 604-630.

Sundberg, F.S. and McCollum, L.B. 2002. Kochiella Poulsen, 1927, and Hadrocephalites new genus (Trilobita: Ptychopariida) from the early Middle Cambrian of Western North America. Journal of Paleontology 76: 76-94.

Sundberg, F.S. and McCollum, L.B. 2003. Trilobites of the lower Middle Cambrian Poliella denticulata Biozone (new) of southeastern Nevada. Journal of Paleontology 77: 331-359.

Thomas, W.A. and Astini, R.A. 1999. Simple-shear conjugate margins of the Argentine Precordillera and the Ouachita embayment of Laurentia. Geological Society of America Bulletin 111: 1069-079.

Vaccari, N.E. 1988. Primer hallazgo de Trilobites del Cámbrico Inferior en la Provincia de La Rioja (Precordillera Septentrional). Revista de la Asociación Geológica Argentina 18: 558-561.

Vaccari, N.E. 1994. [Las faunas de trilobites de las sucesiones carbonáticas del Cámbrico y Ordovícico temprano de la Precordillera Septentrional, República Argentina. Tesis Doctoral, Universidad Nacional de Córdoba, 1-271. Inédito.].

Vaccari, N.E. and Bordonaro, O.L. 1993. Trilobites de los olistolitos cámbricos de la Formación Los Sombreros, Provincia de San Juan, Argentina. Ameghiniana 30: 383-393.

Vaccari, N.E. and Waisfeld, B.G. 2008. The Proto-Andean Margin of Gondwana and accreted terranes: Contrasting biogeographic signatures based on Late Cambrian-Early Ordovician Trilobites. In: I. Rábano, R. Gozalo and D. García-Bellido (eds.), Advances in trilobite research. Cuadernos del Museo Geominero 9: 403-409.

Vaccari, N.E., Waisfeld, B.G., Chatterton, B.D. and Edgecombe, G.D. 2006. New raphiophorid trilobites from the Ordovician of Argentina and their biogeographic implications. Memoirs of the Association of Australasian Paleontologists 32: 353-374.

Walcott, C.D. 1916. Cambrian Geology and Paleontology of Cambrian trilobites. Smithsonian Miscellaneous Collections 64: 303-456.

Walcott, C.D. 1917. Cambrian Geology and Paleontology of Cambrian trilobites, 3, fauna of the Mount White Formation. Smithsonian Miscellaneous Collections 67: 61-114.

Recibido: 26 de marzo de 2009

Aceptado: 26 de abril de 2010 . 